\title{
Okul Müdürü Kavramına İlişkin Metafor Araştırmalarının İncelenmesi: Bir Meta-Sentez Çalışması
}

Meta-sentez

Meta-synthesis

\author{
Metin Kaya ${ }^{1}$ İrfan Koca²
}

\begin{abstract}
Özet
Bu çalışma Türkiye'de 2012-2018 yılları arasında yayınlanmış okul müdürlerine ilişkin 15 nitel metafor araştırmasını meta sentez yöntemiyle incelemektedir. Çalışma sonucunda okul yöneticilerinin insani yeterliliklerinin, teknik ve kavramsal yeterliliklerine göre; olumlu insani özelliklerinin olumsuz insani özelliklerine göre daha sık vurgulandığı belirlenmiştir. Teknik yeterliliklere ilişkin en sık üretilen kategorilerin eğitim-öğretim faaliyeti üretimi, yöneltme ve güç olduğu belirlenmiştir. Kavramsal yeterliliklere ilişkin en sık üretilen kategorinin bilgi kaynağı ve aktarıcı olduğu tespit edilmiştir.
\end{abstract}

Anahtar kelimeler: Okul müdürü, okul yönetimi, okul yöneticisi yeterlilikleri, metafor, meta-sentez

\section{Examining the Metaphor Studies Related to the Concept of School Principal: A Meta-synthesis Study}

\begin{abstract}
In this study, it is aimed to examine 15 qualitative metaphor researches about school principals published between 2012-2018. As a result, it was noticed that the human characteristics of school administrators were emphasized more than their technical and conceptual competencies. Positive human characteristics are treated more often than negative human characteristics. It has been seen that the most frequently produced subthemes related to technical competencies are production-training activities, orientation and power. It has been determined that the most frequently produced category regarding conceptual competencies is the source of information and transmitter.
\end{abstract}

Keywords: School principal, school management, school principal competencies, metaphor, meta - synthesis

1 Bayburt Üniversitesi Eğitim Fakültesi Doktor ögretim Üyesi, metinkaya439@gmail.com ORCID: 00000002-8287-4929

1977 yllında Kars'ta doğmuştur. Lisan eğitimini Dokuz Eylül Üniversitesinde Buca Eğitim Fakültesinde tamamlamıştr. Eğitim yönetimi alanında yüksek lisansını Yeditepe Üniversitesinde, doktora eğitimini Eskişehir Osmangazi Üniversitesinde tamamlamıştır. Bayburt Eğitim Fakültesinde doktor öğretimüyesi olarak çalışmaktadır.

2 Uzman, Okul Müdürü, MEB, irfakoca@gmail.com, ORCID:0000-0003-3442-1308

Lisans eğitimini Gazi Üniversitesỉnde tamaladı. 2002 ylında Milli Eğitim Bakanlığ̉na öğretmen olarak atand. 2020 yllında İstanbul Medeniyet Üniversitesi Eğitim Kurumları İşletmeciliği bölümünde yüksek lisansını tamamladı. İstanbul Ümraniyéde TOKİEsenkent Ortaokulủnda Okul Müdürü olarak görevine devam etmektedir.
Başvuru/Submitted

16 Tem/July 2020

Kabul/Accepted

16 Ağu/Aug 2020

Yayın/Published

09 Eki/Oct 2020

ISSN

2718-0808

Atıf/Cite: Kaya, M. \& Koca, İ. (2020). Okul müdürü kavramına ilişkin metafor araştırmalarının incelenmesi: Bir meta-sentez çalışması. Alanyazın, 1(1), 23-38. http://dx.doi.org/10.22596/ cresjournal.0101.23.38

İçindekiler Table of Contents 


\section{Giriş}

Okulların verimliliği ve etkililiği okul yöneticisi, öğretmen, öğrenci ve velilerinin etkileşimine dayalıdır. Bu etkileşimi yansıtan önemli bir aktör olarak okul müdürleri öne çıkmaktadır. Başka bir ifade ile okul müdürleri okulun değerlerini, ilkelerini, inançlarını, imajlarını yansıtmaktadır (Şahin ve Sabancı, 2018). Okul müdürleri yönetim faaliyetlerini sürdürürken, kişiliklerinde var olan özellikler ve sergiledikleri davranışlar ile yönetim anlayışlarını, stratejilerini ve tekniklerini

Çalışma sonucunda okul yöneticilerinin insani yeterliliklerinin, teknik ve kavramsal yeterliliklerine göre; olumlu insani özelliklerinin olumsuz insani özelliklerine göre daha sık vurgulandığı belirlenmiştir. göstermektedirler (Dönmez, 2008). Okul müdürlerinin hem kişilik özelliklerinden hem sergiledikleri davranışlardan kaynaklanan yönetim yaklaşımları metaforlar aracılığı ile belirlenebilmektedir. Bu sebeple okul yöneticilerine ilişkin metaforların belirlenmesi önemlidir.

Metafor bir deneyimi veya kavramı insanlar tarafından daha iyi bilinen bir başka deneyim veya kavram ile ifade etmek olarak tanımlanmaktadır (Lakoff ve Johnson, 2005). Yıldızlı, Erdol, Baştuğ ve Bayram'ın (2018) çeşitli yazarlardan derledikleri metafor örnekleri şöyledir: 'tartışma savaştır', 'dünya kervansaraydır', 'insan hayvandır', 'güneş insandır'. Okul müdürleri ile ilgili metafor örnekleri şöyle olabilir: 'Okul müdürü babadır', 'okul müdürü fenerdir' Bunlardan okul müdürü ile ilgili birinci metafor okul müdürünün insani bir yeterliliklerini gösterirken ikinci metafor ise okul müdürlerinin kavramsal yeterliliklerini işaret etmektedir.

Okulyöneticilerinin yeterlilikleri, etkin birörgütyönetimiiçin önemlidir.Örgütsel etkinliği ve verimliliği sağlamada okul müdürlerinden beklenen bilgi, beceri ve davranışlar okul yöneticisi yeterlilikleri olarak tanımlanmaktadır (Ağaoğlu, Altınkurt, Yılmaz ve Karaöse, 2012). Katz’a (1956) göre (akt: Bursalığlu, 2012) okul yöneticilerinin yeterliliklerinin insani, teknik ve kavramsal olmak üzere üç ayrı yeterlilik alanından oluştuğunu ifade edilmektedir.

İnsani yeterlilik alanı, okul yöneticisinin birey ve grupları anlama, güdüleme ve insan ilişkilerindekiyeterliliklerikapsamaktadır (Bursalığlu, 2012). İnsani yeterlilik alanı bireysel farkllıkları dikkate alma, işbirlikli çalışma, etkili çalışma ve çalışanlar arasında ortak bir çaba oluşturma gibi özellikleri içermektedir (Özdemir, Bozkurt ve Aydın, 2015). Başaran’a (2004) göre yöneticilerin insani yeterlilik alanını oluşturan ögeler şunlardır: Çalışanlar ile takım çalışması yapma, çalışanları etkili ve verimli çalışmaya güdüleme, çalışanlar arasında uyum sağlama, çalışanların mesleki gelişimine katkı sağlama, çalışanlara rehberlik yapma ve çalışanlar arasında çatışmaları yönetme. Okullar insan ilişkilerinin yoğun yaşandığı kurumlardır. Okul yöneticileri öğretmen, veli ve öğrenciler ile sürekli bir etkileşim içindedir. Bu sebepler ile okulların yönetiminde insan etkileşimi ön plana çıkmaktadır. 
Teknik yeterlilik alanı, okul yöneticiliğinin görevlerine ilişkin bilgi ve becerilerdir. Okul yöneticiliğini etkin olarak yerine getirmek için kullanması gereken teknik, yöntem ve işlemlerden oluşmaktadır (Töremen ve Kolay, 2003). Okul müdürünün yönetim süreçleri; (planlama, örgütleme, yöneltme, eşgüdümleme ve denetim) öğretim yöntem ve teknikleri, program geliştirme, program yönetimi ve problem çözme gibi yeterlilikleri içermektedir (Bursalığlu, 2012). Aydın (2005)’a göre okul yöneticilerinin insan etkileşimleri yanında teknik becerileri olarak etkili bir işletme yönetimi gerçekleştirme, okul binasını ve çevresini hazırlama ve eğitim programlarının yönetimi gibi unsurları vurgulamaktadır.

Kavramsal yeterlilik alanı ise, okul yöneticisinin içinde bulunduğu toplum ve eğitim sistemi bağlamında, eğitim durumlarını kuramsal ve kavramsal olarak analiz ve sentez edebilmesidir. Başka bir ifade ile okul yöneticisinin içinde bulunduğu okulu çok boyutlu ve bir bütün olarak değerlendirmesidir (Bursalığlu, 2012). Okul yöneticisinin yönetim ve eğitim bilimlerinin kuram ve kavramları ile okulu çözümleyebilmesidir (Töremen ve Kolay, 2003).

SEAMEO INNOTECH kuruluşu Güneydoğu Asya ülkelerinde eğitsel problemlere çözüm geliştirmeye dönük bir organizasyondur ve bu organizasyon okul yöneticilerinin yeterlilik alanlarını; stratejik düşünme becerisi ve yenilikçilik, yönetimsel liderlik, öğretimsel liderlik, kişisel mükemmeliyetçilik ve paydaşların katılımını sağlama olarak sinıflamaktadır (Seameo Innotech, 2014). Nomnian ve Arphattananon'a (2018) göre okul yöneticilerinin yeterlilik alanları sırasıyla şöyle tanımlanmaktadır: Stratejik düşünme becerisi ve yenilikçilik alanı, okul yöneticisinin değişimlere uyumu ve bu değişimler doğrultusunda yeni bir eğitim ortamı oluşturmasıdır. Yönetimsel liderlik alanı, eğitim bakanlığının vizyon ve misyonu doğrultusunda öğretmen ve destek hizmeti sunan çalışanların etkin yönetimini kapsamaktadır. Öğretimsel liderlik alanı, öğretmenlerin pedagojik gelişimlerini desteklemek ile ilgili faaliyetleri içermektedir. Kişisel mükemmeliyetçilik alanı, okul yöneticisinin mesleki gelişimini ilerletmesini ifade etmektedir. Paydaşların katılımı sağlama alanı ise okul paydaşlarının yönetime katılmalarını teşvik etme olarak ifade edilmektedir.

Öte yandan Moore ve Rudd (2004) okul yöneticilerinin liderlik yeterlikleri alanlarına insani beceriler, teknik beceriler, kavramsal beceriler dışında duygusal zekâ becerisive sektörel

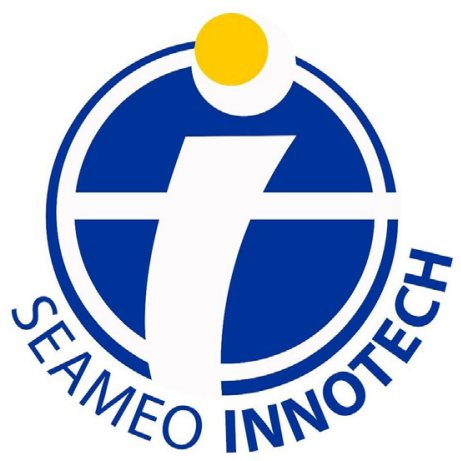
beceriler eklemektedir. Okul yöneticilerinin duygusal becerileri: kendini tanıma, öz düzenleme, duygudaşlık, motivasyon, empati ve sosyal becerileri kapsamaktadır. Sektörel beceriler ise eğitim sektörüne ilişkin bilgi ve becerileri kapsamaktadır. Sözü edilen duygusal zekâ okul yöneticilerinin insani yeterlilik alanı ile ilgilidir. 
Bu çalışmada okul yöneticilerinin yeterlilik alanı konusuna ilişkin Bursalığlu’nun (2012) önerdiği kavramsal çerçeveye göre analizler yapılmıştır.

Okul müdürlerinin içerisinde bulundukları eğitim sistemi bağlamında tanımlanması önemlidir. Okul müdürlerine yönelik metafor araştırmaları hem okul yöneticilerini tanımlayan hem de anlamaya imkan sağlayan çalışmalardır. Aynı zamanda metafor araştırmaları, okul müdürlerinin içerisinde bulunduğu okul kültürü içerisinde tanımlanmasına yardımcı olmaktadır. Alanyazın

\section{Okul müdürlerinin}

içerisinde bulundukları eğitim sistemi bağlamında tanımlanması önemlidir. Okul müdürlerine yönelik metafor araştırmaları hem okul yöneticilerini tanımlayan hem de anlamaya imkân sağlayan çalışmalardır. incelendiğinde okul müdürlerine yönelik ulusal (Ek 1) ve uluslararası (Heffernan, 2019; Hernández-Amorós ve Martínez Ruiz, 2018; Linn, Sherman ve Gill, 2007; Schechter, Shaked, Ganon-Shilon ve Goldratt, 2018; Trnavčevič ve Roncelli Vaupot, 2009) metafor araştırmaları mevcuttur. Türk eğitim sisteminin önemli bir öğesi olan okul yöneticiliğine ilişkin algıların ortaya konması önemlidir. Bu önem bağlamında okul yöneticilerinin özelliklerine ilişkin metafor araştırmaları yapılmıştır. Bu çalışmaların bulgularının sentezlenmesi gereklidir. Okul yöneticiliğine ilişkin algıların ortaya konması okul yöneticiliği mesleğinin gelişimi açısından önemlidir. Öte yandan alan yazın incelendiğinde okul müdürlerine yönelik nitel araştırmaların bulgularını sentezleyen meta-sentez araştırmalarına rastlanmamaktadır. Literatürdeki bu eksikliğin giderilmesi acısından bu çalışmanın önemli olduğu düşünülmektedir.

\section{Amaç}

Bu çalışmada okul müdürlerine ilişkin metafor araştırmalarını incelemek amaçlanmıştır. $\mathrm{Bu}$ amaç doğrultusunda aşağıdaki sorulara yanıt aranmıştır.

1. Okul müdürlüğüne ilişkin metafor inceleme araştırmalarının yıllara göre dağılımı nedir?

2. Okul müdürlügüne ilişkin metafor inceleme araştırmalarının metodolojik (araştırma modeli, örnekleme yöntemi, örnekleme sayısı, katılımcı türü, veri toplama aracı, veri analiz yöntemi) özellikleri nelerdir?

3. Okul müdürlüğüne ilişkin metafor inceleme araştırmalarının ürettiği temalar nelerdir?

4. Okul müdürlügüne ilişkin metafor inceleme araştırmalarının önerileri nelerdir? 


\section{Yöntem}

$\mathrm{Bu}$ çalışmada okul müdürlüğ̈ne ilişkin metafor araştırmalarını incelemek amaçlandığından, çalışma meta- sentez yöntemine göre desenlenmiştir. Meta-sentez aynı konuda yapılan nitel araştırmaların bulgularını birleştirme, yorumlama ve değerlendirme amacıyla yapılmaktadır (Dinçer, 2018; Yıldızlı, Erdol, Baştuğ ve Bayram, 2018). Araştırmalarda meta-sentez yöntemi, incelenen konuya ilişkin bütüncül bir bakış açısıyla yaklaşmak için yapıldığından araştırmacılar tarafından tercih edilmektedir (Polat ve Ay, 2016). Meta-sentez çalışmaları önceden belirlenen işlem basamaklarına göre yürütülmektedir.

Bu çalışma; I) araştırma problemini belirlemek, II) probleme uygun anahtar kelimeleri belirlemek, tarama yapılacak veri tarama kaynaklarını belirlemek ve alan yazın taraması yapmak, III) verilerin toplanması ve değerlendirilmesi, IV) dâhil etme ve hariç tutma ölçütlerinin belirlenmesi ve değerlendirmeye alınacak araştırmaların seçilmesi, V) seçilen araştırmaların çözümlenmesi, ortak temaların ve alt temaların belirlenmesi, benzerlik ve farklılıkların ortaya konması, VI) temalar doğrultusunda çalışmanın bulgularının ortaya konması ve VII) bulguları ayrıntılı bir şekilde raporlama aşamalarına göre yürütülmüştür (Polat ve Ay, 2016).

\section{Veri Toplama Aracı}

Veri toplanma aracı olarak araştırmacı tarafından geliştirilen nitel araştırmaların karakteristik özelliklerini ve içeriğini yansıtıcı bir araştırma formu kullanılmıştır. Araştırma formu üç bölümden oluşmaktadır. Birinci bölüm çalışma setindeki araştırmanın kodu, yayın yıl, araştırma yöntemi, örnekleme yöntemi, örneklem sayısı, katılımcı türü, veri toplama aracı ve veri analiz tekniği başlıklarını kapsamaktadır. İkinci bölümü araştırmaların ürettiği temalar ve kategorilerini kapsamaktadır. Üçüncü bölümü ise araştırmaların ürettiği önerileri kapsamaktadır.

\section{Verilerin Toplanması}

Bu çalışmanın verilerine ULAKBİM, YÖK Akademik, Scopus ve Google Akademik veri tabanlarından erişilmiştir. Türkçe aramalarda metafor, okul müdürü ve okul yöneticisi anahtar kelime olarak kullanılmıştır. İngilizce aramalarda metaphor, school principal ve school administrator, school manager anahtar kelime olarak kullanılmıştır. Anahtar kelimeler metafor ve metaphor kelimeleri diğer anahtar kelimelerle kombinasyonları kurularak arama yapılmıştır. Veri tabanlarında anahtar kelimeler 'başlıkta geçsin' seçeneği kullanılmıştır. Veri tabanlarının ürettiği bağımsız araştırmaların başlık ve özet kısımları incelenmiştir. Bu çalışmanın dahil edilme ölçütlerini karşılama potansiyeli olan araştırmalar seçilerek bir veri havuzu oluşturulmuştur. Bu çalışmaya dahil edilen araştırmalar için aşağıdaki ölçütler geliştirilmiştir. 
1- Okul müdürlügüne ilişkin metafor araştırmaları makale formunda raporlanmış olmalıdır.

2- Okul müdürlügüne ilişkin metafor araştırmaları 2012-2018 ylllar arasında yayınlamış olmalıdır.

3- Okul müdürlüğüne ilişkin metafor araştırmaları nitel araştırma yöntemlerine göre desenlenmiş olmalıdır.

4- Okul müdürlüğüne ilişkin metafor araştırmalarının katılımcıları Türkiye’deki eğitim bölgelerinden olmalıdır.

Veri havuzu toplam 21 araştırmadan oluşmuştur. Farklı veri tabanından gelmiş tekrar eden 4 araştırma ve bildiri formunda 2 araştırma veri havuzundan çıkarılmıştır. $\mathrm{Bu}$ aşamadan sonra veri seti oluşturulmuştur. Bu çalışmanın veri seti 15 araştırmadan oluşmuştur. $\mathrm{Bu}$ araştırmanın veri setini oluşturan araştırmalar ve genel özellikleri Tablo l'de sunulmuştur.

Tablo1: Çalısma setinin özellikleri

\begin{tabular}{|c|c|c|c|c|}
\hline Kodu & Araştırma & Katılımcı & $\begin{array}{l}\text { Araştırma } \\
\text { modeli }\end{array}$ & Veri toplama aracı \\
\hline a1 & Çobanoğlu ve Gökalp (2015) & Öğretmen adayı & Belirtilmemiş & Yarı yapılandırılmış görüşme formu \\
\hline a2 & Yalçın ve Erginer (2012) & $\begin{array}{l}\text { Öğrenci, öğretmen, veli } \\
\text { ve okul yöneticileri }\end{array}$ & Fenomenoloji & Yarı yapılandırılmış görüşme formu \\
\hline a3 & Şahin ve Tüzel (2014) & Öğrenci & $\begin{array}{l}\text { Durum } \\
\text { çalışması }\end{array}$ & $\begin{array}{l}\text { Doküman olarak resim (çizimler) ve } \\
\text { yarı yapılandırılmış görüşme formu }\end{array}$ \\
\hline a4 & Demirbaş ve Alabay (2017). & Öğrenci & Belirtilmemiş & $\begin{array}{l}\text { Doküman olarak resim (çizimler) ve } \\
\text { yarı yapılandırılmış görüşme formu }\end{array}$ \\
\hline a5 & Korkmaz ve Çevik (2018) & Öğretmen & Fenomenoloji & Yarı yapılandırılmış görüşme formu \\
\hline a6 & Akın Kösterelioğlu (2014) & Öğretmen adayı & Fenomenoloji & Açık uçlu sorular \\
\hline a7 & Örücü (2014) & Öğretmen adayı & Tarama & Yarı yapılandırılmış görüşme formu \\
\hline a8 & Akan, Yalçın ve Yıldırım (2014) & Öğretmen & Belirtilmemiş & Yarı yapılandırılmış görüşme formu \\
\hline a9 & Yalçın ve Erginer (2014) & Öğrenci & Fenomenoloji & Doküman olarak resim (çizimler) \\
\hline a10 & Turhan ve Yaraş (2013) & Öğretmen ve öğrenci & Fenomenoloji & Yarı yapılandırılmış görüşme formu \\
\hline a11 & Aslan, Bilgili ve Kaya (2018) & Öğrenci & Belirtilmemiş & Yarı yapılandırılmış görüşme formu \\
\hline a12 & Demirtaş ve Özer (2014). & Okul müdürü & Fenomenoloji & Yarı yapılandırılmış görüşme formu \\
\hline a13 & Şahin ve Sabancı (2018) & $\begin{array}{l}\text { Pedagojik formasyon } \\
\text { öğrencileri }\end{array}$ & Fenomenoloji & Yapılandırılmış soru formu \\
\hline a14 & $\begin{array}{l}\text { Akbaşlı, Üredi, Yolcu ve Loğoğlu } \\
\text { (2017). }\end{array}$ & Öğrenci & Fenomenoloji & Yapılandırılmış soru formu \\
\hline a15 & Akyol ve Kapçak (2017) & Öğretmen adayı & Fenomenoloji & Yarı yapılandırılmış görüşme formu \\
\hline
\end{tabular}


Tablo1'in devamı: Çalışma setinin özellikleri

\begin{tabular}{|c|c|c|c|c|}
\hline Kod & Veri Analiz Yöntemi & Örnekleme & $\begin{array}{l}\text { Örnekl } \\
\text { em }\end{array}$ & Çalıştığı Kurum \\
\hline a1 & İçerik analizi & Bulgulanmadı & 100 & Kategori dışı \\
\hline a2 & İçerik analizi & Bulgulanmadı & 1875 & Ortaokul \\
\hline a3 & $\begin{array}{l}\text { Resimlerin Değerlendirilmesi, } \\
\text { Metaforların Belirlenmesi ve }\end{array}$ & Kolay ulaşılabilir & 173 & ilkokul \\
\hline a4 & içerik analizi & $\begin{array}{l}\text { İki aşamalı örnekleme; ölçüt } \\
\text { örnekleme ve rastlantısal }\end{array}$ & 101 & Okul öncesi \\
\hline a5 & İçerik analizi & Maksimum çeşitlilik & 210 & Ortaokul \\
\hline a6 & İçerik analizi & Kolay ulaşılabilir & 232 & Kategori dışı \\
\hline a7 & İçerik analizi & Kolay ulaşılabilir & 70 & Kategori dışı \\
\hline a8 & İçerik analizi & Bulgulanmadı & 106 & Net belirtilmemiş \\
\hline a9 & İçerik analizi & Maksimum çeşitlilik & 970 & Ortaokul \\
\hline a10 & içerik analizi & Seçkisiz & 160 & ilkokul \\
\hline a11 & İçerik analizi & Seçkisiz & 380 & Lise \\
\hline a12 & Betimsel analiz & Odak grup görüşmesi & 12 & Illköğretim ve lise \\
\hline a13 & İçerik analizi & Kolay ulaşılabilir & 404 & Kategori dışı \\
\hline a14 & İçerik analizi & Bulgulanmadı & 204 & Ortaokul \\
\hline a15 & İçerik analizi & Ölçüt örnekleme & 197 & Kategori dışı \\
\hline
\end{tabular}

\section{Verilerin Analizi}

$\mathrm{Bu}$ çalışmada veriler içerik analizi tekniğine göre çözümlenmiştir. İçerik analizi; bir çalışma setindeki birbirine benzeyen verilerin belirli kategoriler çerçevesinde, sistematik olarak bir araya getirilmesi olarak tanımlanmaktadır (Çalık ve Sözbilir, 2014). İçerik analizinde belirlenen kategoriler okuyucunun kolay anlayabileceği bir biçimde organize edilmekte ve raporlanmaktadır (Özdemir, 2010). Bu çalışmanın kategorilere ilişkin frekans analizleri tablolar ile sunulmuştur.

$\mathrm{Bu}$ çalışmaya dahil edilen araştırmalar araştırmacı tarafından detaylı olarak okunmuş ve elde edilen veriler araştırma formuna işlenmiştir. Araştırma formuna işlenen verilerin benzerlik ve farkllıklarıdikkatealınarakkategorileroluşturulmuştur.Çalışmasetinioluşturanaraştırmaların okul müdürlüğü kavramına ilişkin ürettiği koruyuculuk, sorumluluk sahibi, hoşgörülü, adil gibi kodlar olumlu insani özellikler olarak kodlanmıştır. Çalışma seti oluşturan araştırmaların okul müdürlüğ̈ne ilişkin ürettiği sinirli, yıkııı, tekdüze gibi kodlar olumsuz insani özellikler olarak kodlanmıştır. Olumlu ve olumsuz insani özellikler, okul müdürlüğünün insani özellikleri teması altında toplanmıştır. Çalışma setini oluşturan araştırmaların ürettiği yönetimin faaliyetinin işlevlerine ilişkin kodlama örnekleri şöyledir. Örneğin otokrat, otorite, güç unsuru 
gibi kodlar güç kullanma olarak; bürokrat, mesleki hiyerarşi konumu gibi kodlar statü olarak; danışman, rehber, yol gösterici, yön verici gibi kodlar yöneltme işlevi olarak kodlanmıştır. Yönetim faaliyetlerinin işlevlerine göre yapılan bu kodlamalar okul müdürlügünün teknik özellikleri teması altında toplanmıştır. Çalışma setini oluşturan araştırmaların ürettiği bilgi sahibi, bilgiyi aktaran, aydınlatıcı gibi kodlar okul müdürlüğünün kavramsal özellikleri olarak kodlanmış ve kavramsal özellikler teması altında yorumlanmıştır.

$\mathrm{Bu}$ çalışmanın geçerliliği ve güvenirliği bağlamında, araştırmanın amacı net olarak belirlenmiştir. Çalışmanın amacı doğrultusunda kodlamalar yapılmıştır. Kodlamalar yapılırken kategoriler içi ve kategoriler dışı sürekli karşılaştırma yapılmıştır. Karşılaştırmalar sonucunda uygun kategoriye kodlar yerleştirilmiştir. Kodlanan kategorilerin benzerlik ve farklılıkları dikkate alınmıştır. Benzer kodlar aynı kategori altında toplanmıştır. Kategorileri yerleştirilen kodlar eğitim yönetimi alanında uzman görüşü alınarak yeniden düzenlenmiştir. Kategoriler arası tutarsızlıkla karşılaşılan durumlarda eğitim yönetimi alanında uzman görüşüne başvurulmuştur. Eğitim yönetimi alanında uzman görüşüne uygun olarak tutarsızlık rastlanan kodlar uygun kategorilere yerleştirilmiştir. Ayrıca çalışmanın inandırıcılığına ilişkin olarak çalışma setini oluşturan araştırmalardan doğrudan alıntılara yer verilmiştir (Başkale, 2016).

\section{Bulgular ve Yorum}

Bu bölümde okul müdürlüğüne ilişkin metafor incelemesi yapan çalışmaların genel özellikleri, ürettiği temalar ve önerilere yönelik bulgulara yer verilmiştir. Tablo 2'de okul müdürlügüne ilişkin metafor araştırmalarının genel karakteristik özellikleri sunulmuştur.

Çalışma setini oluşturan araştırmaların en sık 2014 yılında $(\mathrm{f}=6)$ yayınlandığı gözlenmiştir. 2016 yılında okul müdürlüğü kavramına ilişkin metafor incelemesi yapan araştırmaya rastlanmamıştır. Çalışma setini oluşturan araştırmaların katılımcıları sıklıkla öğretmen adayları $(\mathrm{f}=5)$ ve öğrencilerden $(\mathrm{f}=5)$ oluştuğu saptanmıştır. Sözü edilen katılımcıların yanında çalışma setindeki araştırmaların katılımcılarının öğretmen, okul müdürü ve okulun diğer paydaşlarını içeren karma katılımcılardan oluştuğu gözlenmiştir. Çalışma setini oluşturan araştırmalar sıklıkla fenomenolojik modele $(\mathrm{f}=9)$ göre desenlenmiştir. Fenomenolojik modelin yanında durum çalışması modeline ve araştırma deseninin net belirtilmediği araştırmalardan oluştuğu belirlenmiştir. Araştırma deseni net belirtilmeyen araştırmalar, araştırmanın sadece nitel bir araştırma olduğuna vurgu yapan araştırmalardır. 
Tablo2: Çalışma setinin genel özellikleri

\begin{tabular}{|c|c|c|c|}
\hline Yıl & $f$ & Katılımcı & $f$ \\
\hline 2012 & 1 & Öğretmen adayı & 5 \\
\hline 2013 & 1 & Öğrenci & 5 \\
\hline 2014 & 6 & Okul müdürü & 1 \\
\hline 2015 & 1 & Öğretmen & 2 \\
\hline 2017 & 3 & Karma (öğretmen, öğrenci, müdür) & 2 \\
\hline 2018 & 3 & & \\
\hline Desen & $f$ & Veri Analiz Yöntemi & f \\
\hline Fenomenoloji & 9 & İçerik analizi & 13 \\
\hline Durum çalışması & 2 & Betimsel analiz & 1 \\
\hline Net belirtilmemiş & 4 & Resim değerlendirmesi & 1 \\
\hline $\begin{array}{l}\text { Veri Toplama } \\
\text { Aracı }\end{array}$ & $f$ & Örnekleme Yöntemi & $\mathrm{F}$ \\
\hline Yarı yapılandırıımış & 9 & Kolay ulaşılabilir & 4 \\
\hline Yapılandırılmış & 2 & Maksimum çeşitlilik & 2 \\
\hline $\begin{array}{l}\text { Resim (çizimler) ve } \\
\text { yarı yapılandırılmış }\end{array}$ & 2 & Odak grup görüşmesi & 1 \\
\hline Resim (çizimler) & 1 & Ölçüt & 1 \\
\hline \multirow[t]{2}{*}{ Açık uçlu sorular } & 1 & Seçkisiz & 2 \\
\hline & & Net belirtilmemiş & 5 \\
\hline Örneklem Sayısı & $f$ & Kurum Türü & $\mathrm{F}$ \\
\hline 1-100 & 3 & Okulöncesi & 1 \\
\hline $101-200$ & 5 & ilkokul & 2 \\
\hline 201-300 & 3 & Ortaokul & 4 \\
\hline $301-400$ & 1 & Lise & 1 \\
\hline \multirow[t]{3}{*}{ 400- } & 3 & Karma (okul kademeleri karma) & 1 \\
\hline & & Kategori dışı (oğretmen adayı) & 5 \\
\hline & & Net belirtilmemiş & 1 \\
\hline
\end{tabular}


Çalışma setini oluşturan araştırmalar, veri toplama aracı olarak sıklıkla yarı yapılandırılmış görüşme formu $(\mathrm{f}=9)$ kullanmışlardır. Ayrıca veri toplama aracı olarak resim (çizim) ve açık uçlu soruların kullanıldığı görülmektedir. Çalışma setini oluşturan araştırmalar, veri analiz yöntemi olarak sıklıkla içerik analizi yöntemini $(\mathrm{f}=13)$ kullandıkları tespit edilmiştir. Ayrıca çalışma setinde araştırmaların veri analiz yöntemi olarak içerik analizi ve resim değerlendirmesi tekniklerini kullandıkları saptanmıştır. Çalışma setini oluşturan araştırmalarda sıklıkla örnekleme yönteminin net belirtilmediği $(\mathrm{f}=5)$ ve kolay ulaşılabilir $(\mathrm{f}=4)$ örnekleme yöntemine göre örneklem seçildiği ortaya konulmaktadır. Ayrıca örnekleme yöntemi olarak maksimum çeşitlik, ölçüt, seçkisiz örnekleme ve odak grup örnekleme yöntemlerinin tercih edildiği görülmektedir.

Örnekleme yönteminin net belirtilmediği araştırmaların, çalışma grubunu genel özelliklerine göre betimleyen araştırmalar olduğu söylenebilir. Çalışma setini oluşturan araştırmaların örneklem sayısı sıklıkla 101-200 aralı̆̆ındadır ( $\mathrm{f}=5$ ). Ayrıca araştırmaların örneklem sayısı 12 ile 1875 arasında değişmektedir. Çalışma setini oluşturan araştırmaların yürütüldüğü eğitim kademesi sıklıkla ortaokul kademesi $(\mathrm{f}=4)$ olduğu belirlenmektedir. Ayrıca araştırmaların okulöncesi, lise ve sözü edilen kademelere göre karma olarak yürütüldüğü sonucuna ulaşılmıştır. Tablo3’te araştırmaların karakteristik özellikleri ayrıntılı olarak sunulmuştur. 
Tablo3: Okul müdürlerine ilişkin metaforların tematik dağılımı

\begin{tabular}{|c|c|c|}
\hline Tema & Kategori & $f$ \\
\hline \multirow[t]{3}{*}{$\begin{array}{l}\text { İnsani } \\
\text { yeterlilik }\end{array}$} & $\begin{array}{l}\text { Olumlu insani } \\
\text { özellikler }\end{array}$ & 72 \\
\hline & $\begin{array}{l}\text { Olumsuz insani } \\
\text { özellikler }\end{array}$ & 34 \\
\hline & Toplam & $10 €$ \\
\hline \multirow[t]{13}{*}{$\begin{array}{l}\text { Teknik } \\
\text { yeterlilik }\end{array}$} & $\begin{array}{l}\text { Eğitim-öğretim } \\
\text { faaliyeti üretimi }\end{array}$ & 14 \\
\hline & Yöneltme & 14 \\
\hline & Güç & 11 \\
\hline & Yönetim & 9 \\
\hline & Eşgüdüm & 8 \\
\hline & Denetleme & 4 \\
\hline & Planlama & 5 \\
\hline & Yapı kurma & 3 \\
\hline & Statü & 2 \\
\hline & Denge & 2 \\
\hline & Örgütleme & 2 \\
\hline & Karar verme & 1 \\
\hline & Toplam & 75 \\
\hline \multirow[t]{3}{*}{$\begin{array}{l}\text { Kavramsal } \\
\text { yeterlilik }\end{array}$} & $\begin{array}{l}\text { Bilgi kaynağı ve } \\
\text { aktarıcısı }\end{array}$ & 19 \\
\hline & Sorun çözme & 6 \\
\hline & Toplam & 25 \\
\hline
\end{tabular}

Tablo 3'te okul müdürlügüne ilişkin metaforların tematik dağılımları sunulmuştur. Tablo incelendiğinde okul müdürlüğünün insani yeterlilikleri alanına $(\mathrm{f}=106)$ ilişkin vurgunun teknik ( $\mathrm{f}=75)$ ve kavramsal yeterlilik alanına göre $(\mathrm{f}=25)$ daha çok ön plana çıktığ 
gözlenmiştir. Okul müdürlüğüne ilişkin olumlu insani özelliklerinin ( $\mathrm{f}=72)$ olumsuz insani özelliklere ( $\mathrm{f}=34)$ göre daha sık üretildiği saptanmıştır. Okul müdürlüğünün, eğitim öğretim faaliyeti $(\mathrm{f}=14)$, yöneltme $(\mathrm{f}=14)$, güç kullanımı $(\mathrm{f}=11)$ ve eşgüdümleme $(\mathrm{f}=8)$ gibi teknik yeterliliklerine ilişkin kategorilerin diğer yönetim işlevine göre daha sık üretildiği belirlenmiştir. Öte yandan okul müdürlügünün karar verme ve örgütleme işlevlerinin diğer teknik yeterlilikler alanına göre daha nadir üretildiği gözlenmiştir.

Tablo 4'te çalışma setini oluşturan araştırmaların okul müdürlüğune ilişkin metafor incelemesi sonucu araştırmacılar tarafindan üretilen öneriler sunulmuştur.

Tablo4: Çalışma setinin önerilerinin dağılımı

\begin{tabular}{|c|c|c|}
\hline Tema & Önerileriler & $\mathbf{f}$ \\
\hline \multirow[t]{4}{*}{ Politika } & $\begin{array}{l}\text { Öğretmen yetiştirme programına liderlik ve yönetim dersleri } \\
\text { eklenmelidir. }\end{array}$ & 4 \\
\hline & $\begin{array}{l}\text { Okul müdürlerine yönelik algının iyileştirilmesine yönelik önlem } \\
\text { alınmalıdır. }\end{array}$ & 2 \\
\hline & Okul müdürlerinin yetki ve sorumlulukları düzenlenmelidir. & 1 \\
\hline & Okul müdürü atanma ölçütleri düzenlenmelidir. & 1 \\
\hline \multirow[t]{4}{*}{ Uygulama } & Okul müdürleri algılanan müdürün bilincinde olmalıdırlar. & 3 \\
\hline & $\begin{array}{l}\text { Okul müdürleri olumlu iletişim ve etkileşim ortamı } \\
\text { oluşturmalıdırlar. }\end{array}$ & 2 \\
\hline & Okul müdürleri demokratik davranış ve tutum sergilemelidirler. & 1 \\
\hline & Okul müdürleri öğretimsel liderlik rolü sergilemelidirler. & 1 \\
\hline \multirow[t]{3}{*}{ Araştırma } & $\begin{array}{l}\text { Okul paydaşlarına ve okul kademelerine göre müdür algılarını } \\
\text { irdeleyen nicel ve nitel araştırmalar yapılmalıdır. }\end{array}$ & 3 \\
\hline & $\begin{array}{l}\text { Okul müdür algısının zamanla değişimini inceleyen zaman serili } \\
\text { araştırmalar yapılmalıdır. }\end{array}$ & 1 \\
\hline & $\begin{array}{l}\text { Okul paydaşlarının hayalindeki müdürü irdeleyen araştırmalar } \\
\text { yapılmalıdır. }\end{array}$ & 1 \\
\hline
\end{tabular}


Çalışma setini oluşturan araştırmaların okul müdürlüğü politikalarına yönelik, daha sık ürettiği öneri, "Öğretmen yetiştirme programına liderlik ve yönetim dersleri eklenmelidir." şeklindedir. Uygulamaya yönelik çalışma setindeki araştırmaların en sık ürettiği öneri, "Okul müdürleri, algılanan okul müdürünün bilincinde olmalıdırlar." şeklindedir.
Araştırmalar ürettikleri temalar açısından incelendiğinde, okul müdürlerinin olumlu insanı özelliklerine ilişkin temaların sıklıkla üretildiği sonucuna erişilmiştir. Bunun yanı sıra okul müdürlerine yönelik olumsuz insani özelliklerin de önemli düzeyde üretildiği sonucuna varılmıştır.

\section{Sonuç ve Tartışma}

$\mathrm{Bu}$ araştırmada okul müdürlerine yönelik Türkiye bağlamında nitel araştırmaların bulgularının meta sentez yöntemi ile değerlendirilmesi amaçlanmıştır. Bu çerçevede okul müdürlerine yönelik metafor araştırmaları incelenmiş ve bu araştırmaların bulguları değerlendirilmiştir.

Araştırmalar metodolojik özelliklerine göre incelendiğinde nitel araştırma desenleri içerisinde çoğunlukla fenomenolojik araştırmalar olduğu sonucuna ulaşılmıştır. Bunun yanında bazı araştırmalarda nitel araştırma yönteminin hangi desene uygun olarak yürütüldügünden net bahsedilmemesi ise dikkat çekicidir. Araştırmaların kullandıkları veri toplama araçları açısından incelendiğinde, sıklıkla yarı yapılandırılmış görüşme formlarının kullanıldığı sonucuna erişilmiştir. Araştırmalar veri analiz teknikleri açısından incelendiğinde elde edilen verilerin çoğunlukla içerik analizi tekniği ile analiz edildiği sonucuna varılmıştır. Araştırmalar katılımcıları açısından incelendiğinde okul müdürlügüne yönelik metafor araştırmalarının, öğrenciler, öğretmenler, öğretmen adayları ve okul müdürleri üzerinden yürütüldügü sonucuna ulaşılmıştır. Sözü edilen katılımcıların okul müdürleri ile yakın ilişkide olan ve etkileşen eğitim paydaşları olmaları açısından önemli olduğu düşünülebilir. Bu araştırmanın metodolojik özellikleri Yıldızlı ve arkadaşlarının (2018) yaptığı araştırma sonuçları ile karşılaştırıldığında benzer olduğu söylenebilir. Bu durum metafor araştırmaların metodolojik eğilimlerinin birbirine benzer olduğunu gösterebilir. Okul müdürlerine ilişkin olarak insani özelliklerin hem teknik hem de kavramsal yeterlilik temalarından daha sık üretildiği sonucuna varılmıştır. Bu durum, katılımcların okul müdürlüğ̈nü mesleki olarak insan ilişkilerinin ön planda olduğu bir çalışma sahası olarak algıladığını ortaya koymaktadır.

Araştırmalar ürettikleri temalar açısından incelendiğinde, okul müdürlerinin olumlu insanı özelliklerine ilişkin temaların sıklıkla üretildiği sonucuna erişilmiştir. Bunun yanı sıra okul müdürlerine yönelik olumsuz insani özelliklerin de önemli düzeyde üretildiği sonucuna varılmışır. 
Erçetin ve Eriçok (2016) okul müdürlerinin empati, iyimser olma, çevre ile iletişim, dışa dönük olma, hoşgörü, saygil olma, sorumluk sahibi olma, güvenilir olma, evrensel değerlere bağh olma, dürüst olma, yaratıcı olma, yenilikçi ve vizyon sahibi olma gibi kişisel ve ahlaki yeterliliklerin etkili okul müdürlerinde bulunması gereken özellikler olduğunu vurgulamaktadır. Erdoğan (2006); Özdemir, Bozkurt ve Aydın (2015) okul müdürlerinin insani özelliklerinin önemini vurgulamakta ve etkin bir okul yöneticinin önemli bir yeterlik alanı olduğunu ifade etmektedirler.
Araştırmaların önerileri incelendiğinde eğitim politikalarına yönelik öneriler içerisinde öğretmen eğitimi programlarında liderlik ve yönetici ders programlarının eklenmesini vurgulamaktadır. Uygulamaya yönelik öneri olarak okul yöneticilerinin okul ortamı içerisinde algılanan okul yöneticisinin bilincinde olması gerektiği öne çıkmaktadır.

Ayrıca okul müdürlerinin teknik özelliklerine ilişkin temalar da saptanmıştır. Teknik özelliklere ilişkin en sık üretilen temaların eğitim-öğretim faaliyeti üretimi, yöneltme ve güç olduğu sonucuna erişilmiştir. Teknik özelliklere ilişkin en nadir üretilen temalar ise statü, denge, örgütleme, karar verme olduğu tespit edilmiştir. Erçetin ve Eriçok (2016) teknik yeterlik olarak insan kaynağı yönetimi, katılımcı karar alma, yetki devri, okulda eğitim ve ögretim faaliyeti üretme temalarının araştırmalarda ön plana çıktığını vurgulamaktadırlar. $\mathrm{Bu}$ çalışmanın bulguları ile sözü edilen çalışmanın bulguları kısmen örtüşmektedir. $\mathrm{Bu}$ durumun okul yöneticilerinin teknik yeterliliklerinin kapsamının geniş olmasından kaynaklandığı söylenebilir.

Öte yandan okul müdürlerinin kavramsal yeterliliklerine ilişkin üretilen tema bilgi kaynağı ve aktarıcı teması olduğu sonucuna varılmıştır. Erçetin ve Eriçok (2016) okul yöneticilerinin bilgilendirme yeterliklerinin sıklıkla araştırmacılar tarafından vurgulandığını saptamıştır. $\mathrm{Bu}$ çalışmanın sonuçları ile sözü edilen çalışmanın bulgularının örtüştüğü söylenebilir.

Araştırmaların önerileri incelendiğinde eğitim politikalarına yönelik öneriler içerisinde öğretmen eğitimi programlarında liderlik ve yönetici ders programlarının eklenmesini vurgulamaktadır. Uygulamaya yönelik öneri olarak okul yöneticilerinin okul ortamı içerisinde algılanan okul yöneticisinin bilincinde olması gerektiği öne çıkmaktadır. Ayrıca araştırmacılara yönelik okul paydaşlarına ve okul kademelerine göre okul yöneticisi algılarını irdeleyen karma araştırmalar yapılması önerilmektedir. 


\section{Kaynaklar / References}

Ağaoğlu, E., Altınkurt, Y., Yılmaz, K., \& Karaöse, T. (2012). Okul yöneticilerinin yeterliklerine ilişkin okul yöneticilerinin ve öğretmenlerin görüşleri (Kütahya ili). Eğitim ve Bilim, 37(164), 159-175.

*Akan, D., Yalçın, S., \& Yıldırım, İ. (2014). ‘Okul müdürü’ kavramına ilişkin öğretmenlerin metaforik algıları. İlköğretim Online, 13(1),169-179.

*Akbaşli, S., Üredi, L., Yolcu, H., \& Loğoğlu, P. K. (2017). Analyzing the metaphorical perceptions of secondary education students related to mathematics teacher and mathematics course. Kastamonu Education Journal, 25(6), 2283-2292.

*Akın Kösterelioğlu, M. (2014). Öğretmen adaylarının okul yöneticisi kavramına ilişkin metaforik algıları. Journal of World of Turks, 6(3), 115-133.

*Akyol, B., \& Kapçak, C. B. (2017). Pre-Service teachers' perceptions of "administration" and "school principal” reflected through metaphors. European Journal of Education Studies 3(10), 293-309.

*Aslan, O., Bilgili, A., \& Kaya, A. V. (2018). Liselerde okuyan öğrencilerin okul müdürüne ilişkin metaforik alg1lar1. Bilim Armonisi, 1(1), 11-17.

Aydın, M. (2005). Eğitim yönetimi. Ankara: Hatiboğlu Basım Yayın San. Tic. Ltd.

Başaran, İ. E. (2004). Yönetimde insan ilişkileri: Yönetsel davranış. Ankara: Nobel Yayın Dağıtım.

Başkale, H. (2016). Nitel araştırmalarda geçerlik, güvenirlik ve örneklem büyüklüğünün belirlenmesi. Dokuz Eylül Üniversitesi Hemşirelik Fakültesi Elektronik Dergisi, 9(1),23-28.

Bursalığlu, Z. (2012). Okul yönetiminde yeni yapı ve davranış (17. Baskı). Ankara: Pegem Akademi.

Çalık, M., \& Sözbilir, M. (2014). İçerik analizinin parametreleri. Eğitim ve Bilim, 39(174). 33-38.

*Çobanoğlu, N., \& Gökalp, S. (2015). Öğretmen adaylarının okul müdürüne ilişkin metaforik algıları. Mustafa Kemal Üniversitesi Sosyal Bilimler Enstitüsü Dergisi, 12(31), 279-295.

*Demirbaş, S., \& Alabay, E., (2017). Okul öncesi dönem çocukların müdür algılarının belirlenmesi. Mehmet Akif Ersoy Üniversitesi Eğitim Fakültesi Dergisi, 41, 78-97.

*Demirtaş, H., \& Özer, N. (2014). Okul müdürlerinin bakış açısıyla okul müdürlüğü. Kastamonu Eğitim Dergisi, 22(1), 1-24.

Dinçer, S. (2018). Eğitim bilimleri araştırmalarında içerik analizi: meta-analiz, meta-sentez, betimsel içerik analizi. Bartın Üniversitesi Eğitim Fakültesi Dergisi, 7(1), 176-190.

Dönmez, Ö. (2008). Türk eğitim sisteminde kullanılan yönetici metaforları. (Yayınlanmamış yüksek lisans tezi). Erciyes Üniversitesi, Kayseri.

Erçetin, Ş. Ş., \& Eriçok, B. (2016). Yayınlarda yer alan okul yöneticilerinin yeterliklerinin analizi (ULAKBİM 2004-2016). Electronic Turkish Studies, 11(14),239-256.

Erdoğan, İ. (2006). Okul yöneticilerinin genel özellikleri ve yöneticilik tutumlarıyla ilgili bir araştırma. HAYEF Journal of Education, 3(1), 103-118.

Heffernan, A. (2019). The 'punk rock principal': a metaphor for rethinking educational leadership. Journal of Educational Administration and History, 51(2), 117-132.

Hernández-Amorós, M. J., \& Martínez Ruiz, M. A. (2018). Principals' metaphors as a lens to understand how they perceive leadership. Educational Management Administration \& Leadership, 46(4), 602623.

*Korkmaz, M., \& Çevik, M. S. (2018). Ortaokul öğretmenlerinin müdür kavramına ilişkin metaforik algıları. Kuramsal Eğitimbilim Dergisi, 11(4), 973-1002.

Lakoff, G. ve Johnson, M. (2005). Metaforlar hayat, anlam ve dil (G. Y. Demir, Çev.). Paradigma, İstanbul.

Linn, G. B., Sherman, R., \& Gill, P. B. (2007). Making meaning of educational leadership: The principalship in metaphor. NASSP Bulletin, 91(2), 161-171. 
Moore, L. L., \& Rudd, R. D. (2004). Leadership skills and competencies for extension directors and administrators. Journal of Agricultural Education, 45(3), 22-33.

Nomnian, S., \& Arphattananon, T. (2018). School Administrators' competencies for effective english language teaching and learning in Thai government primary schools. IAFOR Journal of Education, 6(2), 51-69.

*Örücü, D. (2014). Öğretmen adaylarının okul, okul yönetimi ve Türk eğitim sistemine yönelik metaforik algiları. Kuram ve Uygulamada Eğitim Yönetimi Dergisi, 20(3), 327-358.

Özdemir, G., Bozkurt, A. T., \& Aydın, T. (2015). Okul yöneticilerinin insancil yeterlikleri. Elementary Education Online, 14(1), 151-163.

Özdemir, M. (2010). Nitel veri analizi: Sosyal bilimlerde yöntembilim sorunsalı üzerine bir çalışma. Eskişehir Osmangazi Üniversitesi Sosyal Bilimler Dergisi, 11(1), 323-343.

Polat, S. \& Ay O. (2016). Meta-sentez: kavramsal bir çözümleme. Eğitimde Nitel Araştırmalar Dergisi, 4(2), $52-64$.

SEAMEO INNOTECH (2014). Competency framework for Southeast Asian school heads: 2014 Edition 01.02. 2020 tarihinde https://www.seameo-innotech.org/wp-content/uploads/2015/02/CompetencyFramework-for-Southeast-Asian-School-Heads-2014.pdf adresinden erişilmiştir.

Schechter, C., Shaked, H., Ganon-Shilon, S., \& Goldratt, M. (2018). Leadership metaphors: School principals' sense-making of a national reform. Leadership and Policy in Schools, 17(1), 1-26.

*Şahin, A., \& Sabancı, A. (2018). Pedagojik formasyon eğitimi öğrencilerinin okul yöneticileri ile öğretmenlere ilişkin algıları: metafor çalışması. Turkish Studies, 13(4), 1057-1082.

*Şahin, D., \& Tüzel, E. (2014). İlköğretim birinci kademe öğrencilerinin okul yöneticilerine ilişkin metaforları. Adıyaman Üniversitesi Sosyal Bilimler Enstitüsü Dergisi, 17, 355-396.

Töremen, F., \& Kolay, Y. (2003). İlköğretim okulu yöneticilerinin sahip olması gereken yeterlikler. Milli Eğitim Dergisi, 160.01.02.2020 tarihinde http://dhgm.meb.gov.tr/yayimlar/dergiler/Milli_Egitim_ Dergisi/160/ toremen-kolay.htm adresinden erişilmiştir.

Trnavčevič, A., \& Roncelli Vaupot, S. (2009). Exploring aspiring principals' perceptions of principalship: A Slovenian case study. Educational Management Administration \& Leadership, 37(1), 85-105.

*Turhan, M., \& Yaraş, Z. (2013). Öğretmen ve öğrencilerin öğretmen, disiplin, müdür, sınıf kuralları, ödül ve ceza kavramlarına ilişkin metafor algıları. Firat Üniversitesi Sosyal Bilimler Dergisi, 23(1), 129145 .

*Yalçın, M., \& Erginer, A. (2012). İlköğretim okullarında okul müdürüne ilişkin metaforik algılar. Journal of Teacher Education and Educators, 1(2), 229-256.

*Yalçın, M., \& Erginer, A. (2014). İlköğretim okulu öğrencilerinin okul müdürü algılarına ilişkin yaptıkları çizimler. Eğitim ve Bilim, 39(171), 270-285.

Yıldızlı, H., Erdol, T. A., Baştuğ, M., \& Bayram, K. (2018). Türkiye’de öğretmen kavramı üzerine yapılan metafor araştırmalarına yönelik bir meta-sentez çalışması. Eğitim ve Bilim, 43(193),1-43. 